\title{
SHOW DA QUÍMICA: RELATO DE UM PROJETO DE EXTENSÃO
}

Paulo Roberto Cunha dos Santos ${ }^{1}$

\section{RESUMO}

A escola pública sofre com o desestímulo dos componentes principais do processo de ensino-aprendizagem: o professor e os alunos. Na formação dos professores, em geral, existe uma carência e/ou deficiência, notadamente, na área de ciências da natureza. Dessa forma, a necessidade de mecanismos que resgatem a qualidade do ensino nas escolas públicas é iminente. Neste contexto, o IFRN - Campus Santa Cruz pode desempenhar um papel importante, buscando desenvolver o conhecimento de Química na região do Trairi através de projetos de extensão como o Show da Química, no qual se busca promover atividades que ofereçam condições para promover a difusão e popularização da ciência usando como ferramenta amostras experimentais itinerantes nas escolas públicas e também por meio do desenvolvimento de um site de divulgação do referido Projeto. Objetivase, assim, neste artigo, relatar, em linhas gerais, como foi desenvolvido o projeto de extensão denominado Show da Química.

Palavras-chave: Show da Química; Experimentos Químicos; Conhecimento científico.

\section{INTRODUÇÃO}

O mundo vive uma nova ordem, caracterizada por conhecimento, inovação, tecnologia, descoberta e transformação. É nesse mundo que nossos alunos vivem e é nele que vão intervir. Sendo assim, para que eles entendam o mundo à sua volta, a cultura científica é tão necessária quanto o letramento e o despertar do pensamento matemático. Isso é ainda mais necessário em um país como o Brasil, que convive com grandes disparidades sociais e econômicas.

O ensino de Química, muitas vezes, tem-se resumido à memorização de fórmulas e nomenclaturas utilizadas nessa área específica. Ativida- des com experimentos, quando realizados, limitam-se a demonstrações, não envolvem a participação ativa do aluno, ou apenas os convidam a seguir um roteiro, sem levar em consideração o caráter investigativo/problematizador e a possibilidade de relação entre o experimento, os conceitos e sua aplicabilidade em situações reais (CLEALLAN, 1984).

A não contextualização da química pode ser responsável pelo alto nível de rejeição do estudo desta ciência pelos alunos, dificultando o processo de ensino-aprendizagem (TARDIF,1999). Em relação à formação dos docentes para o Ensino Fundamental, pode-se dizer que temos uma formação ineficiente que não prepara os professores 
para a contextualização dos conteúdos, principalmente, em relação às ciências exatas.

O desenvolvimento do projeto em relato começou com a participação dos estudantes bolsistas em uma busca por situações do cotidiano, para que desenvolvessem experimentações, e produzissem registros escritos, entre outros procedimentos que contribuem para o avanço da construção de seus conhecimentos científicos. O professor coordenador e orientador do Projeto procurou desenvolver, em suas aulas, cursos semanais ou oficinas para que os alunos aprendessem os conhecimentos teóricos e experimentais das ações que iriam ser apresentadas à comunidade.

a. Durante todo o processo ocorreram as seguintes etapas:

b. Levantamento bibliográfico (BALZAR,1995: BRASIL,2001 e 2006; SEVERINO,2004; TARDIF,2002);

C. Elaboração de práticas laboratoriais;

d. Apresentação do Show da Química, Avaliação;

e. Preparação de um site com informações didáticas sobre o projeto Show da Química.

\section{DESENVOLVIMENTO DO PROJETO}

O show da Química é um projeto de curso de extensão que está sendo desenvolvido desde 2013 no IFRN-Campus Santa Cruz. Tem como finalidade propagar os conhecimentos químicos na região do Trairi do Rio Grande do Norte, fazendo a divulgação e a popularização da educação científica desenvolvida no referido Campus.

Para sua execução, são preparados alunos do IFRN para apresentar a Química através de demonstrações experimentais a um público que não tem domínio deste conhecimento. Os alunos antes de irem para as demonstrações devem ter aprendido com professor/coordenador a relacionar a teoria com a prática, utilizando temas relevantes e interessantes. Em seguida, vão para escolas onde realizam experimentos estudados, fazendo uso dos conhecimentos aprendidos. Toda ação externa é coordenada também, sob a orientação do professor/coordenador. Nesse projeto, além dos alunos bolsistas, a comunidade escolar também pode aprender a importância da Química como ciência básica e aplicada à tecnologia e ao cotidiano.
Já foram visitadas cinco escolas no estado do Rio Grande do Norte: Escola Estadual João Ferreira (Santa Cruz); Escola Estadual Doutor José Borges (Campo Redondo); Escola Estadual Oscarlina Marques (Santa Cruz); Escola Estadual Quintino Bocaiuva (Santa Cruz); Escola Municipal Francisca Oliveira (Natal) e o projeto também já participou da Exposição Científica, Tecnológica e Cultural - Expotec, IFRN (Santa Cruz), com experimentos e oficinas. Foi criada também ainda, uma página virtual na qual há informações sobre as ações e experimentos utilizados. As Figuras 1 e 2 mostram algumas atividades experimentais realizadas no projeto.

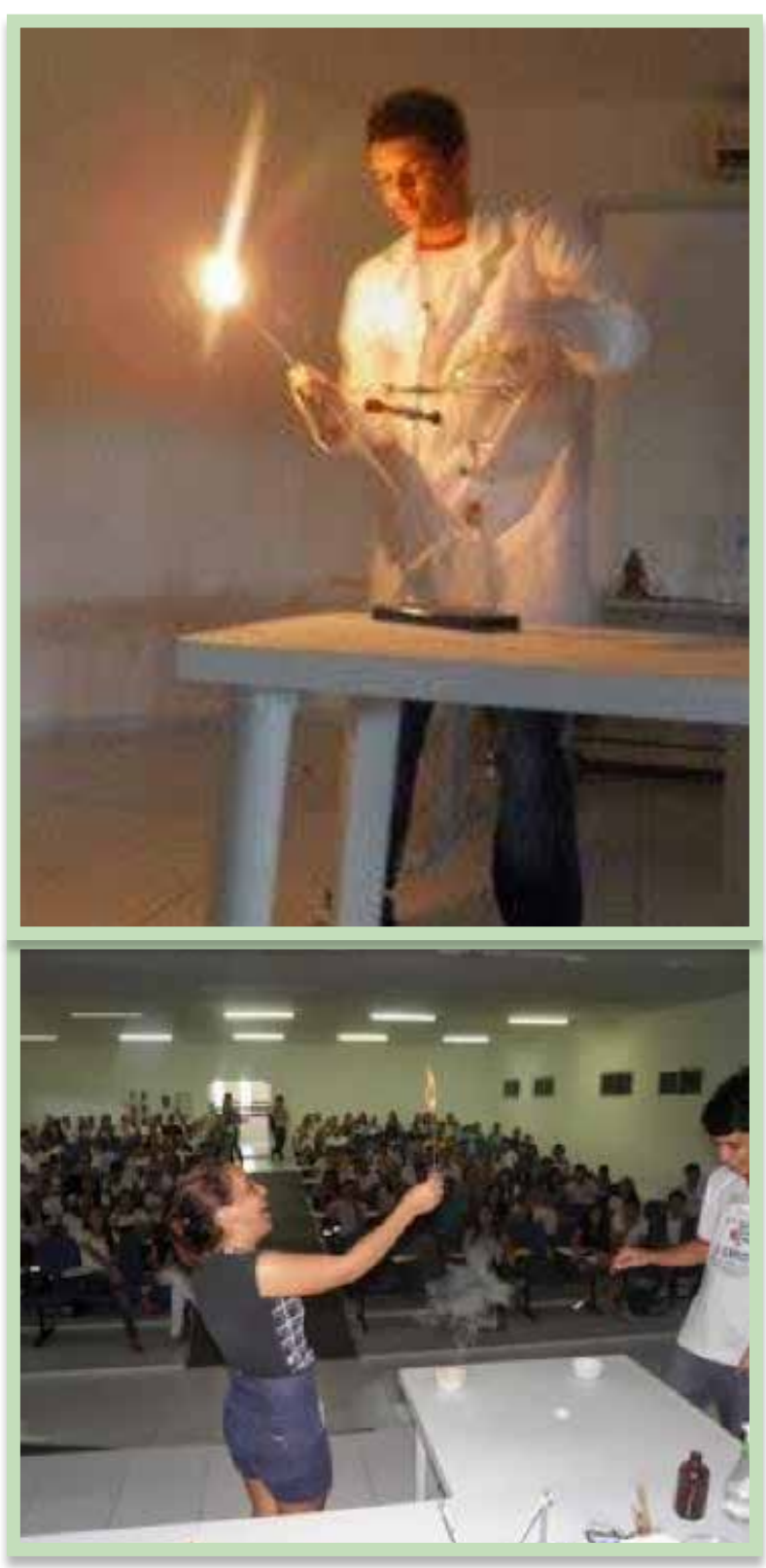

Figura 1: experimentos realizados pelo Projeto Show da Química-IFRN (maçarico químico e varinha mágica) 
